\title{
TREE SPECIES DIVERSITY IN THE FOREST OF RENIKHAYONG PARA VILLAGE IN BANDARBAN, BANGLADESH: A CASE STUDY
}

\author{
Jannat, M., M. Kamruzzaman, M. A. Hossain and M. K. Hossain \\ Institute of Forestry and Environmental Sciences, University of Chittagong, Chattogram - 4331, \\ Bangladesh
}

\begin{abstract}
The study was conducted to explore tree species diversity of Renikhayong para Village Common Forest (VCF) of Bandarban hill district. Stratified random sampling was carried out to assess the tree species diversity of the VCF. Renikhayong Para VCF with an area of 40 acres of land has more than 85 tree species belonging to 31 families, where Euphorbiaceae family was dominant containing 11 species followed by Rubiaceae ( 7 species), Moraceae ( 7 species), Meliaceae ( 5 species), Mimosaceae (5 species), Combretaceae (4 species), Lauraceae (4 species) and Anacardiaceae (3 species). Dominant tree species was Grewia nervosa. Renikhayong para VCF has diverse floristic resources that are known from the Shannon-Wiener's diversity index (4.007), Simpson's diversity index (0.028), Margalef's richness index (13.21) and Species evenness index (0.90). However, number of species and number of individuals both were highest in the height range of 5 $-<10 \mathrm{~m}$. Similar trend was observed in dbh classes. Number of individuals were highest in dbh range of 5 $<15 \mathrm{~cm}$ and the lowest in $\geq 55 \mathrm{~cm}$. The results depict the presence of maximum small trees in the VCF and decreasing the number of trees with the increase of tree height $(\mathrm{m})$ and $\mathrm{dbh}(\mathrm{cm})$. Presence of diverse tree species and diversity indices indicate the importance and potential of the VCF for conservation and sustainable use.
\end{abstract}

Key words: Village Common Forest; Indigenous communities; Importance Value Index; Biological diversity; Diversity indices; Heterogeneous composition.

\section{INTRODUCTION}

Village common forests (VCF), managed by indigenous communities in Chittagong Hill Tracts (CHT), are essentially repositories of food, biodiversity and medicinal plants and their management have set a standard model for the protection of biodiversity, environment and natural resources (Baten $e t$ al. 2010). VCF shows a rich biodiversity in comparison to government managed reserve forests in Chittagong Hill Tracts (CHT) (Baten et al. 2010, Adnan and Dastidar 2011). VCF are good examples of effective community based forest management under certain customary rules and regulations in CHT (Halim and Roy 2006, Baten et al. 2010). Since time immemorial forest has been used by the tribal population for hunting ground, gathering food, swidden (jhum) cultivation, grazing, charcoal making and collection of minor forest products including medicinal or herbal produces as major means of livelihood (Roy 2000, 2002, Halim and Roy 2006, Chowdhury 2008).

The world is now in a stage of transition, triggered by environmental crises and vulnerabilities where maintaining sustainability in all development initiatives is crucial, not only for scientist and decision makers, but for long term survival of the earth system (Azam and Sarker 2011). There is growing evidence that local community-based entities are good and often better managers of forests in comparison to regional, national and local governments (White and Martin 2002, Rasul and Thapa 2005, Rasul and Karki 2006). In Chittagong Hill Tracts (CHT) different ethnic communities traditionally maintain a common forest area which is known as Village Common Forest (VCF) or Parabon or Mouza reserve etc. (Jashimuddin and Inoue 2012). The VCF's management responsibility goes to the respective community which depends largely on water sources and forest common to fulfill its basic subsistence requirements and cash income (Miah and Chowdhury 2004, Rasul and Karki 2006, Rasul 2007).

However, there is no valid information on the tree species diversity of Renikhayong para VCF, a 
fascinating hill region of Bandarban hill district situated in the southeastern part of the country. Thus, the present study was carried out with the aim of exploring tree species diversity of Renikhayong para Village Common Forest (VCF) in Bandarban hill district.

\section{MATERIAL AND METHODS}

Study area

The study was carried out in Bandarban hill district located in the Southeast side of Bangladesh between $21.15^{\circ}$ and $22.20^{\circ} \mathrm{N}$ latitudes, and $91.05^{\circ}$ and $92.40^{\circ}$ E longitudes. The area of Bandarban district is about 4,479 square kilometers with two-thirds of its area characterized by steep slopes. Renikhayong para village was established in 1990 and at present about 32 families are living there. On the other hand, Renikhayong para VCF was established after three years of village establishment. The VCF area is about 40 acres and 22 kilometers away from sadar upazila. There is no electricity in this village. Inhabitants of this village use GFS or Chora as their source of drinking water.

\section{Sampling methods}

The methods of the study consist of reconnaissance survey, field survey, data analysis and report writing. To have an idea about location, accessibility, communication means and VCF area prior to selection of sampling procedure, field visits as well as formal discussion was conducted with Tahzingdong a local Non-Governmental Organization.

Stratified random sampling was carried out for the inventory of the tree species. The sampling plot size for tree species diversity was $20 \mathrm{~m} \times 20 \mathrm{~m}$. Height and dbh of tree species in each plot were measured. All the trees having dbh of $\geq 5 \mathrm{~cm}$ were measured and recorded. Basal area, relative density, relative frequency, relative dominance and Importance Value Index (IVI) were calculated following Shukla and Chandal (2000). Four diversity indices, i.e. Shannon-Wiener's index (H), Simpson's diversity index (D), Margalef's species richness index (R) and Species evenness index (E) were analyzed following Shannon and Wiener (1963), Simpson (1949), Margalef (1958) and Pielou (1966), respectively to get a picture of tree species diversity in Renikhayong para VCF. Several transact walks across the VCF was made following Chattergy et al. (2000).

\section{RESULTS AND DISCUSSION}

The study was carried out in Renikhayong para VCF of Bandarban district. It is about $22 \mathrm{~km}$ away from the Sadar Upazila. This VCF was established in 1993 (Table 1).

Table 1. General information of VCF studied in Bandarban district.

\begin{tabular}{|l|c|}
\hline Village & Renikhayong para \\
\hline Mouza & 9 no. ward Renikhayong mouza \\
\hline Year of village establishment & 1990 \\
\hline Total household (No.) & 32 \\
\hline Current population of the village (No.) & 180 \\
\hline Year of VCF establishment & 1993 \\
\hline Area (Acre) & 40 \\
\hline Distance (km) from Sadar Upazilla & 22 \\
\hline Electricity availability & No \\
\hline Drinking water sources & GFS, Chora \\
\hline
\end{tabular}

The results of the study revealed that Renikhayong para VCF possesses 576 individuals of 85 tree species belonging to 31 families. Among the recorded species, six species are not yet identified. The dominant family was Euphorbiaceae with 11 species followed by Rubiaceae ( 7 species), Moraceae (7 
species), Meliaceae (5 species), Mimosaceae (5 species), Combretaceae (4 species), Lauraceae (4) and Anacardiaceae (3 species) (Table 2). Apocynaceae, Bignoniaceae, Burseraceae, Clusiaceae, Dilleniaceae, Ebenaceae, Myrtaceae, Sterculiaceae and Tiliaceae families have two species in each family and the remaining families possess only one species each (Table 2).

Table 2. Tree species with their local, scientific and family names at Renikhayong para VCF.

\begin{tabular}{|c|c|c|c|}
\hline Family & Scientific name & Local name & No. of trees \\
\hline \multirow{3}{*}{ Anacardiaceae } & Lannea coromandelica (Houtt.) Merr. & Bhadi & 13 \\
\hline & Spondias pinnata (L.f) Kurz & Jongli amra & 3 \\
\hline & Mangifera sylvatica Roxb. & Uriam & 8 \\
\hline \multirow{2}{*}{ Apocynaceae } & Alstonia scholaris (L.) R. Br. & Chatian & 12 \\
\hline & Holarrhena antidysenterica (L.) Wall. ex Decne & Kuruch & 9 \\
\hline \multirow{2}{*}{ Bignoniaceae } & Stereospermum colais (Buch.-ex Dillw.) Mabberley & Dharmara & 22 \\
\hline & Oroxylum indicum (L.) Kurz & Thona/Kanaidinga & 4 \\
\hline Bombacaceae & Bombax insigne Wall. & Shimul Tula & 10 \\
\hline \multirow{2}{*}{ Burseraceae } & Canarium resiniferum Brace ex King. & Dhup & 3 \\
\hline & Protium serratum (Wall. ex Coelbr.) Engl. & Gutgutiya & 16 \\
\hline Caesalpiniaceae & Saraca asoca (Roxb.) de Wild. & Ashok & 2 \\
\hline \multirow{2}{*}{ Clusiaceae } & Garcinia cowa Roxb. ex DC. & Jongli Kao & 1 \\
\hline & Mesua ferrea $\mathrm{L}$. & Nageshwar & 4 \\
\hline \multirow{4}{*}{ Combretaceae } & Terminalia bellirica (Gaertn.) Roxb. & Bohera & 6 \\
\hline & Terminalia chebula Retz. & Haritaki & 4 \\
\hline & Anogeissus acuminata (Roxb. ex DC.) Gull. \& Perr. & Sikori & 11 \\
\hline & Terminalia sp. & Badam & 14 \\
\hline \multirow{2}{*}{ Dilleniaceae } & Dillenia indica $\mathrm{L}$. & Chalta & 3 \\
\hline & Dillenia pentagyna Roxb. & Hargeza & 2 \\
\hline Dipterocarpaceae & Anisoptera scaphula (Roxb.) Pierre & Boilam & 4 \\
\hline \multirow{2}{*}{ Ebenaceae } & Diospyros montana Roxb. & Bon Gab & 1 \\
\hline & Diospyros sp. & $\mathrm{Gab}$ & 2 \\
\hline Elaeocarpaceae & Elaeocarpus tectorius (Lour.) Poir. & Jalpai & 3 \\
\hline \multirow{11}{*}{ Euphorbiaceae } & Glochidion multiloculare (Roxb. ex Wild.) Muell.-Arg. & Aniatori/Pannyatori & 26 \\
\hline & Suregada multiflora (A. Juss.) Bail. & Ban-naranga & 4 \\
\hline & Callicarpa arborea Roxb. & Bormala & 7 \\
\hline & Bridelia $\mathrm{sp}$ & Bridelia sp. & 3 \\
\hline & Macaranga denticulata (Blume) Mull.-Arg. & Bura & 3 \\
\hline & Sapium baccatum Roxb. & Champata & 1 \\
\hline & Gmelina arborea Roxb. & Gamar & 43 \\
\hline & Aporosa dioica (Roxb.) Muell.-Arg. & Harula & 3 \\
\hline & Aporosa wallichii Hook.f. & Kechua & 5 \\
\hline & Baccaurea ramiflora Lour. & Lotkon & 1 \\
\hline & Mallotus philippensis (Lamk.) Mull.-Arg. & Sindhuri & 3 \\
\hline Fabaceae & Erythrina fusca Lour. & Mandar & 2 \\
\hline Fagaceae & Lithocarpus sp. & Batna & 1 \\
\hline Flacourtiaceae & Flacourtia jangomas (Lour.) Raeusch. & Painnagula & 2 \\
\hline \multirow{5}{*}{ Lauraceae } & Actinodaphne sp. & Bhuiya & 4 \\
\hline & Cinnamomum verum C.Presl & Jongli Daruchini & 1 \\
\hline & Litsea glutinosa (Lour.) Robinson & Menda & 8 \\
\hline & Actinodaphne angustifolia Ness & Modon mosta/Tejmatan & 4 \\
\hline & Litsea monopetala (Roxb.) Pers. & Oirga & 2 \\
\hline Leeaceae & Leea macrophylla Roxb. ex Hornem. & Chaigas & 8 \\
\hline Lythraceae & Lagerstroemia speciosa (L.) Pers. & Jongli Jarul & 1 \\
\hline Magnoliaceae & Michelia champaca $\mathrm{L}$. & Champa & 2 \\
\hline Meliaceae & Walsura robusta Roxb. & Bon Lichu & 2 \\
\hline
\end{tabular}




\begin{tabular}{|c|c|c|c|}
\hline & Chukrasia tabularis A. Juss. & Chickrassi & 1 \\
\hline & Swietenia macrophylla King & Mehogoni & 3 \\
\hline & Aphanamixis polystachya (Wall.) R.N. Parker & Pitraj & 3 \\
\hline & Toona ciliata M. Roem. & Toon & 3 \\
\hline \multirow{5}{*}{ Mimosaceae } & Albizia chinensis (Osb.) Merr. & Chakua Koroi & 14 \\
\hline & Albizia procera (Roxb.) Benth & Koroi & 8 \\
\hline & Albizia lebbeck (L.) Benth. \& Hook. & Kalo Koroi & 5 \\
\hline & Albizia lucidior (Steud.) I.C.Nielsen & Sil-Koroi & 11 \\
\hline & Albizia odoratissima (L.f.) Benth. & Tetuya Koroi & 5 \\
\hline \multirow{7}{*}{ Moraceae } & Ficus pyriformis Hook. \& Arn. & Bon Dumur & 2 \\
\hline & Artocarpus lacucha Buch.-Ham & Borta & 2 \\
\hline & Ficus benghalensis L. & Bot & 2 \\
\hline & Artocarpus chama Buch.-Ham. ex Wall. & Chapalish & 16 \\
\hline & Ficus hispida L.f. & Dumur & 5 \\
\hline & Ficus sp. & Ficus sp. & 11 \\
\hline & Ficus racemosa $\mathrm{L}$. & Jogya Dumur & 2 \\
\hline Myristicaceae & Myristica linifolia Roxb. & Amberala & 9 \\
\hline \multirow{2}{*}{ Myrtaceae } & Syzygium cumini (L.) Skeels & Jam & 7 \\
\hline & Syzygium fruticosum (Wall.) Masamune & Putijam & 10 \\
\hline \multirow{7}{*}{ Rubiaceae } & Hymenodictyon orixensis (Roxb.) Mabb. & Ful Gamari & 4 \\
\hline & Neolamarckia cadamba (Roxb.) Bosser & Kadam & 8 \\
\hline & Neonauclea sessilifolia (Roxb.) Merr. & Kom & 4 \\
\hline & Haldina cordifolia (Roxb.) Ridsdale & Konnaari & 2 \\
\hline & Mussaenda sp. & Musanda & 3 \\
\hline & Psychotria sp. & Bara Sudma & 5 \\
\hline & Morinda angustifolia Roxb. & Ronggas & 9 \\
\hline Sonneratiaceae & Duabanga grandiflora (Roxb. ex DC.) Wall. & Bandorhola & 8 \\
\hline \multirow{2}{*}{ Sterculiaceae } & Sterospermum semisegitattum Buch. -Ham. ex Roxb. & Lana-achar & 5 \\
\hline & Sterculia villosa Roxb. ex Smith & Udal & 8 \\
\hline Theaceae & Schima wallichii (DC.) Korth. & Kanak & 7 \\
\hline \multirow{2}{*}{ Tiliaceae } & Grewia nervosa (Lour.) Panigr. & Assargula & 53 \\
\hline & Brownlowia elata Roxb. & Moos & 8 \\
\hline Verbenaceae & Vitex peduncularis Wall. ex Schauer & Goda/Arsol & 13 \\
\hline \multirow{6}{*}{ Unidentified } & Unidentified-1 & Dormum sing & 2 \\
\hline & Unidentified-2 & Mamching & 4 \\
\hline & Unidentified-3 & Puronja & 5 \\
\hline & Unidentified-4 & Puronma & 9 \\
\hline & Unidentified-5 & Ramiyat & 4 \\
\hline & Unidentified-6 & Turong & 3 \\
\hline
\end{tabular}

Diversity indices

Different biological diversity index values were calculated to depict tree species diversity of the VCF studied. Shannon-Wiener's Diversity Index was found 4.007 where Simpson's Diversity Index was 0.028. Moreover, Margalef's Richness Index was calculated as 13.21 and Species Evenness Index was 0.90 (Table 3).

Table 3. Biological diversity indices for recorded tree species in the VCF.

\begin{tabular}{cc}
\hline Name of the indices & Diversity index Values \\
\hline Shannon-Wiener's Diversity Index (H) & 4.007 \\
Simpson's Diversity Index (D) & 0.028 \\
Margalef's Richness Index (R) & 13.21 \\
Species Evenness Index (E) & 0.90 \\
\hline
\end{tabular}


Quantitative structure of tree species at Renikhayong para VCF

Grewia nervosa possesses the highest (88.33) stem/ha followed by Gmelina arborea (71.67), Glochidion multiloculare (43.33), Stereospermum colais (36.67), Protium serratum (26.67) and Artocarpus chama (26.67). The study reveals that Artocarpus lacucha occupied the highest basal area $\left(0.16 \mathrm{~m}^{2}\right)$ followed by Ficus benghalensis $\left(0.15 \mathrm{~m}^{2}\right)$, Terminalia bellirica $\left(0.14 \mathrm{~m}^{2}\right)$ and Diospyros montana $\left(0.12 \mathrm{~m}^{2}\right)$. Relative density was found maximum in Grewia nervosa $(9.20 \%)$ followed by Gmelina arborea (7.47\%), Glochidion multiloculare (4.51\%), Stereospermum colais (3.82\%), Protium serratum (2.78\%) and Artocarpus chama (2.78\%).

Grewia nervosa showed the highest (3.94\%) relative frequency followed by Glochidion multiloculare (3.66\%), Gmelina arborea (3.38\%), Stereospermum colais (3.28\%), Protium serratum (2.82\%) and Artocarpus chama (2.54\%). Relative dominance was found highest in Artocarpus lacucha (5.38\%) followed by Ficus benghalensis (5.15\%), Terminalia bellirica (4.76\%) and Diospyros montana $(4.2 \%)$.

The highest Importance Value Index (IVI) was found in Grewia nervosa (13.41) followed by Gmelina arborea (12.87), Stereospermum colais (10.96), Glochidion multiloculare (8.37), Albizia lucidior (7.21) and Terminalia spp. (7.15) (Table 4). The IVI value helps in decision to select priority species for conservation program (Shibru 2002).

Table 4. Stem/ha, BA $\left(\mathrm{m}^{2}\right)$, relative density, relative frequency, relative dominance and Importance Value Index (IVI) of tree species recorded at Renikhayong para VCF.

\begin{tabular}{|c|c|c|c|c|c|c|}
\hline Scientific name & Stem/ha & BA $\left(\mathrm{m}^{2}\right)$ & RD (\%) & RF (\%) & RDo (\%) & IVI \\
\hline Actinodaphne sp. & 6.67 & 0.01 & 0.69 & 0.85 & 0.33 & 1.87 \\
\hline Myristica linifolia & 15.00 & 0.05 & 1.56 & 1.41 & 1.62 & 4.59 \\
\hline Glochidion multiloculare & 43.33 & 0.01 & 4.51 & 3.66 & 0.19 & 8.37 \\
\hline Saraca asoca & 3.33 & 0.01 & 0.35 & 0.56 & 0.40 & 1.31 \\
\hline Grewia nervosa & 88.33 & 0.01 & 9.20 & 3.94 & 0.26 & 13.41 \\
\hline Duabanga grandiflora & 13.33 & 0.09 & 1.39 & 1.41 & 3.16 & 5.95 \\
\hline Suregada multiflora & 6.67 & 0.06 & 0.69 & 0.85 & 1.99 & 3.53 \\
\hline Lithocarpus sp. & 1.67 & 0.04 & 0.17 & 0.28 & 1.24 & 1.70 \\
\hline Lannea coromandelica & 21.67 & 0.06 & 2.26 & 1.97 & 1.88 & 6.11 \\
\hline Terminalia bellirica & 10.00 & 0.14 & 1.04 & 1.13 & 4.76 & 6.93 \\
\hline Anisoptera scaphula & 6.67 & 0.03 & 0.69 & 0.85 & 1.13 & 2.67 \\
\hline Ficus pyriformis & 3.33 & 0.01 & 0.35 & 0.56 & 0.38 & 1.29 \\
\hline Diospyros montana & 1.67 & 0.12 & 0.17 & 0.56 & 4.20 & 4.94 \\
\hline Walsura robusta & 3.33 & 0.04 & 0.35 & 0.28 & 1.23 & 1.86 \\
\hline Callicarpa arborea & 11.67 & 0.06 & 1.22 & 1.69 & 1.94 & 4.84 \\
\hline Artocarpus lacucha & 3.33 & 0.16 & 0.35 & 0.56 & 5.38 & 6.29 \\
\hline Ficus benghalensis & 3.33 & 0.15 & 0.35 & 0.56 & 5.15 & 6.06 \\
\hline Bridelia sp. & 5.00 & 0.02 & 0.52 & 0.56 & 0.51 & 1.59 \\
\hline Macaranga denticulata & 5.00 & 0.02 & 0.52 & 0.56 & 0.73 & 1.81 \\
\hline Leea macrophylla & 13.33 & 0.01 & 1.39 & 1.41 & 0.10 & 2.90 \\
\hline Albizia chinensis & 23.33 & 0.05 & 2.43 & 1.97 & 1.59 & 5.99 \\
\hline Dillenia indica & 5.00 & 0.01 & 0.52 & 0.56 & 0.48 & 1.56 \\
\hline Michelia champaca & 3.33 & 0.01 & 0.35 & 0.56 & 0.23 & 1.14 \\
\hline Sapium baccatum & 1.67 & 0.01 & 0.17 & 0.28 & 0.07 & 0.53 \\
\hline Artocarpus chama & 26.67 & 0.01 & 2.78 & 2.54 & 0.44 & 5.75 \\
\hline Alstonia scholaris & 20.00 & 0.03 & 2.08 & 2.25 & 0.88 & 5.22 \\
\hline Chukrasia tabularis & 1.67 & 0.01 & 0.17 & 0.28 & 0.51 & 0.96 \\
\hline Stereospermum colais & 36.67 & 0.11 & 3.82 & 3.38 & 3.76 & 10.96 \\
\hline Canarium resiniferum & 5.00 & 0.01 & 0.52 & 0.85 & 0.47 & 1.84 \\
\hline Diospyros sp. & 3.33 & 0.01 & 0.35 & 0.56 & 0.50 & 1.41 \\
\hline Ficus hispida & 8.33 & 0.03 & 0.87 & 1.13 & 0.89 & 2.88 \\
\hline
\end{tabular}




\begin{tabular}{|c|c|c|c|c|c|c|}
\hline Ficus sp. & 18.33 & 0.01 & 1.91 & 2.54 & 0.37 & 4.82 \\
\hline Hymenodictyon orixensis & 6.67 & 0.05 & 0.69 & 0.85 & 1.68 & 3.22 \\
\hline Gmelina arborea & 71.67 & 0.06 & 7.47 & 3.38 & 2.03 & 12.87 \\
\hline Vitex peduncularis & 21.67 & 0.01 & 2.26 & 1.97 & 0.23 & 4.46 \\
\hline Protium serratum & 26.67 & 0.01 & 2.78 & 2.82 & 0.33 & 5.92 \\
\hline Dillenia pentagyna & 3.33 & 0.06 & 0.35 & 0.56 & 2.00 & 2.91 \\
\hline Terminalia chebula & 6.67 & 0.06 & 0.69 & 0.85 & 2.16 & 3.70 \\
\hline Aporosa dioica & 5.00 & 0.01 & 0.52 & 0.85 & 0.46 & 1.82 \\
\hline Elaeocarpus tectorius & 5.00 & 0.04 & 0.52 & 0.85 & 1.28 & 2.64 \\
\hline Syzygium cumini & 11.67 & 0.01 & 1.22 & 1.69 & 0.27 & 3.18 \\
\hline Ficus racemosa & 3.33 & 0.02 & 0.35 & 0.56 & 0.52 & 1.43 \\
\hline Spondias pinnata & 5.00 & 0.07 & 0.52 & 0.85 & 2.36 & 3.73 \\
\hline Cіпnатотит verum & 1.67 & 0.01 & 0.17 & 0.28 & 0.20 & 0.66 \\
\hline Lagerstroemia speciosa & 1.67 & 0.04 & 0.17 & 0.28 & 1.36 & 1.81 \\
\hline Garcinia cowa & 1.67 & 0.04 & 0.17 & 0.28 & 1.23 & 1.68 \\
\hline Swietenia macrophylla & 5.00 & 0.01 & 0.52 & 0.56 & 0.07 & 1.15 \\
\hline Neolamarckia cadamba & 13.33 & 0.11 & 1.39 & 1.41 & 3.60 & 6.40 \\
\hline Schima wallichii & 11.67 & 0.06 & 1.22 & 1.13 & 1.90 & 4.24 \\
\hline Aporosa octandra & 8.33 & 0.01 & 0.87 & 1.13 & 0.14 & 2.14 \\
\hline Neonauclea sessilifolia & 6.67 & 0.03 & 0.69 & 0.85 & 1.17 & 2.71 \\
\hline Haldina cordifolia & 3.33 & 0.03 & 0.35 & 0.56 & 1.01 & 1.92 \\
\hline Albizia procera & 13.33 & 0.07 & 1.39 & 1.69 & 2.31 & 5.39 \\
\hline Holarrhena antidysenterica & 15.00 & 0.01 & 1.56 & 1.97 & 0.43 & 3.96 \\
\hline Sterospermum semisegitattum & 8.33 & 0.01 & 0.87 & 0.85 & 0.41 & 2.12 \\
\hline Baccaurea ramiflora & 1.67 & 0.01 & 0.17 & 0.28 & 0.10 & 0.55 \\
\hline Erythrina fusca & 3.33 & 0.01 & 0.35 & 0.28 & 0.48 & 1.11 \\
\hline Litsea glutinosa & 13.33 & 0.01 & 1.39 & 1.69 & 0.28 & 3.36 \\
\hline Actinodaphne angustifolia & 6.67 & 0.01 & 0.69 & 1.13 & 0.25 & 2.07 \\
\hline Brownlowia elata & 13.33 & 0.01 & 1.39 & 1.41 & 0.33 & 3.13 \\
\hline Mussaenda sp. & 5.00 & 0.01 & 0.52 & 1.13 & 0.27 & 1.92 \\
\hline Mesua ferrea & 6.67 & 0.01 & 0.69 & 0.85 & 0.21 & 1.75 \\
\hline Litsea monopetala & 3.33 & 0.01 & 0.35 & 0.28 & 0.23 & 0.85 \\
\hline Flacourtia jangomas & 3.33 & 0.01 & 0.35 & 0.56 & 0.35 & 1.26 \\
\hline Aphanamixis polystachya & 5.00 & 0.01 & 0.52 & 0.56 & 0.25 & 1.33 \\
\hline Psychotria sp. & 8.33 & 0.02 & 0.87 & 0.85 & 0.74 & 2.45 \\
\hline Syzygium fruticosum & 16.67 & 0.01 & 1.74 & 1.41 & 0.25 & 3.39 \\
\hline Morinda angustifolia & 15.00 & 0.01 & 1.56 & 1.69 & 0.38 & 3.63 \\
\hline Albizia lebbeck & 8.33 & 0.03 & 0.87 & 0.85 & 0.93 & 2.64 \\
\hline Bombax insigne & 16.67 & 0.04 & 1.74 & 1.69 & 1.26 & 4.68 \\
\hline Anogeissus acuminata & 18.33 & 0.02 & 1.91 & 1.97 & 0.78 & 4.66 \\
\hline Albizia lucidior & 18.33 & 0.10 & 1.91 & 1.97 & 3.32 & 7.21 \\
\hline Mallotus philippensis & 5.00 & 0.01 & 0.52 & 0.56 & 0.45 & 1.53 \\
\hline Terminalia sp. & 23.33 & 0.06 & 2.43 & 2.54 & 2.18 & 7.15 \\
\hline Albizia odoratissima & 8.33 & 0.05 & 0.87 & 0.85 & 1.78 & 3.49 \\
\hline Oroxylum indicum & 6.67 & 0.01 & 0.69 & 0.85 & 0.29 & 1.83 \\
\hline Toona ciliata & 5.00 & 0.09 & 0.52 & 0.85 & 2.95 & 4.32 \\
\hline Sterculia villosa & 13.33 & 0.01 & 1.39 & 1.13 & 0.40 & 2.92 \\
\hline Mangifera sylvatica & 13.33 & 0.01 & 1.39 & 1.69 & 0.09 & 3.17 \\
\hline Unidentified-1 & 3.33 & 0.04 & 0.35 & 0.56 & 1.22 & 2.13 \\
\hline Unidentified-2 & 6.67 & 0.08 & 0.69 & 1.13 & 2.78 & 4.60 \\
\hline Unidentified-3 & 8.33 & 0.01 & 0.87 & 1.13 & 0.47 & 2.47 \\
\hline Unidentified-4 & 15.00 & 0.01 & 1.56 & 1.69 & 0.39 & 3.65 \\
\hline Unidentified-5 & 6.67 & 0.02 & 0.69 & 1.13 & 0.65 & 2.47 \\
\hline Unidentified-6 & 5.00 & 0.06 & 0.52 & 0.56 & 2.03 & 3.11 \\
\hline Total & & & 100.00 & 100.00 & 100.00 & 300.00 \\
\hline
\end{tabular}


Percentage distribution of tree species in height $(m)$ classes

Percentage distribution of tree individuals into different height $(\mathrm{m})$ classes showed that height range $(5$ - <10) $\mathrm{m}$ holds maximum $(45.49 \%)$ percentage of tree individuals. The minimum percentage $(2.78 \%)$ was represented by the height range $(25-<30) \mathrm{m}$. Both the number of species and number of individuals decreased regularly with the increase of total height (m) (Fig. 1).

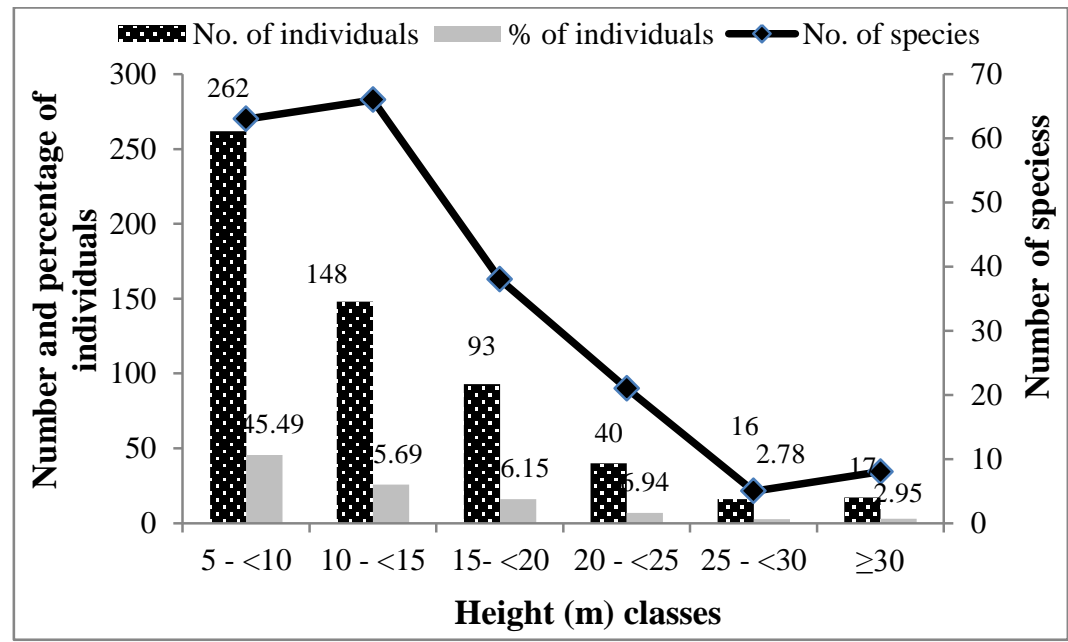

Fig. 1. Distribution of tree height (m) classes at Renikhayong Para VCF.

\section{Percentage distribution of tree species in $\mathrm{DBH}(\mathrm{cm})$ classes}

Percentage distribution of tree individuals into different $\mathrm{dbh}(\mathrm{cm})$ classes showed that dbh range $(5$ $<15) \mathrm{cm}$ holds maximum $(56.60 \%)$ percentage of tree individuals. The minimum percentage $(3.3 \%)$ was represented by the height range $\geq 55 \mathrm{~cm}$. Both the number of species and number of individuals decreased regularly with the increase of total dbh (Fig. 2).

The study revealed that Renikhayong para VCF supports 576 individuals of 85 tree species belonging to 31 families. Baten et al. (2010) recorded 173 floral species from the VCF in CHT. Similarly Basak et al. (2014) recorded 148 plant species from Murong community managed 20 ha sized Ampupara VCF in Bandarban of which 82 are tree species. Mohiuddin and Paul (2018) recorded 76 indigenous tree species from Nirbanpur Buddha Bihar (kiyang) in Rangamati. Whereas tree diversity is higher in Protected Areas, e.g. Hossain and Hossain (2014) reported 240 tree species under 61 families from Chunati Wildlife Sanctuary. A total of 182 tree species belonging to 50 families was recorded from Dhudpukuria-Dophachari Wildlife Sanctuary (DDWS) (Feeroz et al. 2012). Feeroz et al. (2011) reported 142 tree species belonging to 57 families from Rema- Kalenga Wildlife Sanctuary. Renikhayong para VCF has more than 85 tree species belonging to 31 families which is quite poor than that of the PAs. This may be because of smaller area (only 40 acre) of VCF studied. However, Malaker et al. (2010) reported 78 tree species from Lawachara National Park. Sobuj and Rahman (2010) reported 26 tree species from Khadimnagar National Park. About 82 species under 31 families were found in Dulahazara Safari Park (Uddin and Misbahuzzaman, 2007). Renikhayong para VCF shows a rich biodiversity compared to government managed reserve forests in CHT (Baten et al. 2010, Adnan and Dastidar 2011, Jashimuddin and Inoue 2012) and the results are in accordance with the present findings. 


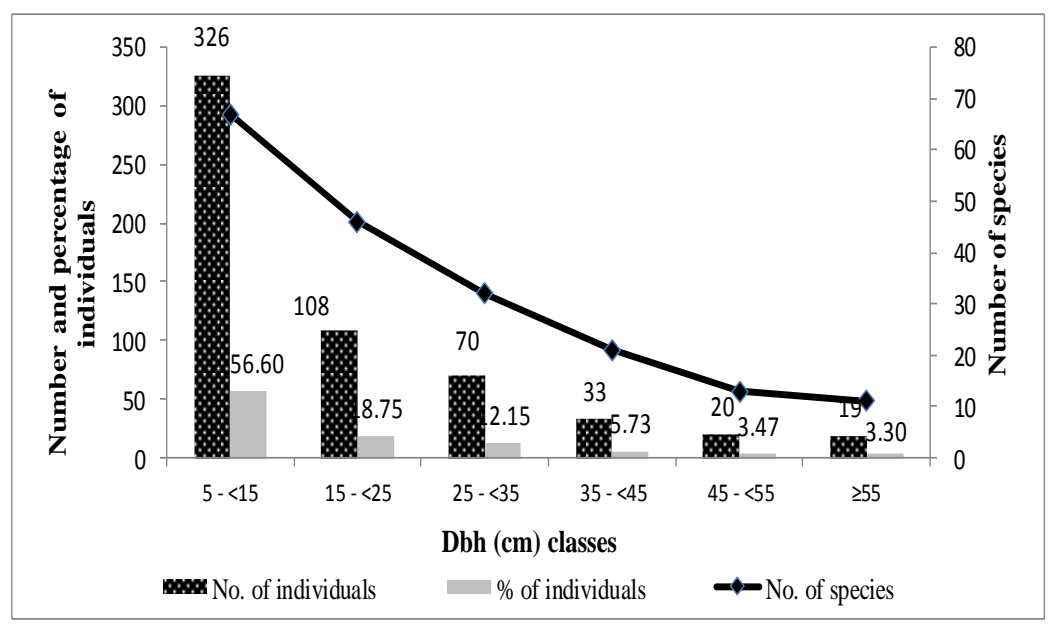

Fig. 2. Distribution of tree dbh (cm) classes at Renikhayong para VCF.

The Shannon-Wiener's Diversity Index (4.007) found in the present study is higher than that of 2.98 in Sitapahar reserve forest (Nath et al. 2000) and 3.25 in Tankawati natural forest in Chittagong (South) Forest Division (Motaleb and Hossain 2011). The index is comparable to Shannon-Wiener's Diversity Index (4.449) found in Dhudpukuria- Dhopachori Wildlife Sanctuary (Hossain et al. 2013) and 4.27 of Garo Hills of India (Kumar et al. 2006). The Value of Shannon-Wiener's Index (4.007) and Margalef's Index (13.21) and lower value of Simpson's Index (0.028) in the present study indicate higher species diversity in Renikhayong para VCF of Bandarban compared to other natural forests of the country. Shannon-Wiener Index found in the present study was 4.007 which is similar to the findings of Tripathi et al. (2004), Kumar et al. (2006), Velho and Krishnadas (2011), and Ndah et al. (2013). They found Shannon-Wiener Index within 3.50 - 4.27 for natural forests.

Species Evenness Index was found 0.90 in the present study which is similar to the findings of Tripathi et al. (2004), Ndah et al. (2013), Panda et al. (2013). They reported species Evenness Index within 0.88-0.99. However, present findings are quite higher compared to the findings of Bhuiyan et al. (2003) and Hayat et al. (2010). Simpson's index was found 0.028 which is comparable with the findings of Ndah et al. (2013) and Panda et al. (2013).

In the present study, both the number of species and number of individuals were highest in the height range of $5-<10 \mathrm{~m}$. Number of species and number of individuals were found highest in the dbh range of $5-<15 \mathrm{~cm}$ in the present study which is almost similar with the findings of Nath et al. (1997). They found maximum individuals in the dbh range of 10-19.9 cm for the natural forests of CHT South Forest Division.

Most of the VCFs in Bandarban are more heterogeneous both in floral and faunal composition. Even though biodiversity is decreasing day by day, but still the VCFs are enriched with high biodiversity. In CHT, local people are dependent on forest produces for their everyday needs and Jannat et al. (2018) investigated the people's dependency and contribution of forest to the livelihoods in three hill district of Bangladesh. Moreover, present study provides a complete view of tree species diversity, quantitative structure of Renikhayong para VCF which are situated in Bandarban district. Presence of 85 tree species and value of diversity indices indicate the importance and potentiality of the VCF for conservation of natural ecosystem. Various diversity indices, regular distribution of tree species in different height and dbh (diameter at breast height) classes indicate the rich biodiversity and existence of complex ecosystem functions in the study area. The present study may serve as a primary input towards further study on vegetation structure and carbon pool assessment. 


\section{ACKNOWLEDGEMENTS}

The authors are thankful to the Arannayk Foundation and Tahzingdong for providing the supports for this study in Bandarban hill District. Sincere thanks to the Bangladesh Forest Research Institute (BFRI) and local people of Renikhayong Para VCF in Bandarban district for their support in the field.

\section{REFERENCES}

Adnan, S. and R. Dastidar. 2011. Alienation of the lands of indigenous people in the Chittagong Hill Tracts of Bangladesh. Chittagong Hill Tracts Commission/International Work Group for Indigenous Affairs, Dhaka/Copenhagen. 252 pp.

Azam, M. and T. Sarker. 2011. Green tourism in the context of climate change towards sustainable economic development in the South Asian Region. J. Environ. Manage. Tourism. 1: 6-15.

Basak, S. R., M. Mohiuddin, M. K. Alam and S. Alam. 2014. Plant Diversity of Village Common Forests Managed by the Murang Community in Bandarban Hill District of Bangladesh. Bangladesh J. Forest Sci. 33(1\&2): 11-20.

Baten, M. A., N. A. Khan, R. Ahmmad and K. Misbahuzzaman. 2010. Village common forests in Chittagong Hill Tracts, Bangladesh: Balance between Conservation and Exploitation. Unnayan Onneshan-The Innovators, Dhaka. 13 pp.

Bhuiyan, P., M. L. Khan and R. S. Tripathi. 2003. Tree diversity and population structure in undisturbed and human-impacted stands of tropical wet evergreen forest in Arunachal Pradesh, Eastern Himalayas and India. Biodivers. Conserv. 12: 1753-1773.

Chattergy, K. K., K. J. I. Khan and D. Jap. 2000. PRA in Bangladesh. Dhaka. 152 pp.

Chowdhury, K. 2008. Politics of identities and resources in Chittagong Hill Tracts, Bangladesh: Ethno nationalism and/or indigenous identity. Asian J. Social Sci. 36: 57-78.

Feeroz, M. M., M. K. Hasan and M. K. Hossain. 2012. Biodiversity of Protected Areas of Bangladesh: Dudpukuria- Dhopachari Wildlife Sanctuary. Vol. 2. Arannayk Foundation. Dhaka, Bangladesh.

Feeroz, M.M., M.K. Hasan, and M.M.H. Khan. 2011. Biodiversity of Protected Areas of Bangladesh: Rema-Kalenga Wildlife Sanctuary. Vol. 1. Arannayk Foundation. Dhaka, Bangladesh. 214 pp.

Halim, S. and R. D. Roy. 2006. Lessons learned from the application of human rights-based approaches in the indigenous forestry sector in the Chittagong Hill Tracts, Bangladesh: A case study of the village common forest project implemented by Taungya. $29 \mathrm{pp}$.

Hayat, M. A., K. A. Kudus, I. Faridah-Hanum, A. A. Noor and M. Nazre. 2010. Assessment of Plant Species Diversity at Pasir Tengkorak Forest Reserve, Langkawi Island, Malaysia. J. Agri. Sci. 2: 31-38.

Hossain, M. A., M. K. Hossain, M. A. Salam and S. Rahman. 2013. Composition and diversity of tree species in Dudpukuria- Dhopachori Wildlife Sanctuary of Chittagong (South) Forest Division, Bangladesh. Res. J. Pharmaceutical Biol. Chemical Sci. 4(2): 1447-1457.

Hossain, M. K. and M. A. Hossain. 2014. Biodiversity of Chunati Wildlife Sanctuary: Flora. Arannayk Foundation and Bangladesh Forest Department. Dhaka, Bangladesh. 175 pp.

Jannat, M., M. K. Hossain, M. M. Uddin, M. A. Hossain and M. Kamruzzaman. 2018. People's dependency on forest resources and contributions of forests to the livelihoods: a case study in Chittagong Hill Tracts (CHT) of Bangladesh. Int. J. Sust. Develop. World Ecol. 25(6): 554-561. 
Jashimuddin, M. and M. Inoue. 2012. Management of Village Common Forests in the Chittagong Hill Tracts of Bangladesh: Historical Background and Current Issues in Terms of Sustainability. Open J. Forestry. 2(3):121-137.

Kumar, A., B. G. Marcot and A. Saxena, 2006. Tree species diversity and distribution patterns in tropical forests of Garo Hills. Current Science. 91: 1370-1381.

Malaker, J. C., M. M. Rahman, A. K. M. A. Prodhan, S. K. Malaker and M. A. H. Khan. 2010. Floristic composition of Lawachara forest in Bangladesh. Int. J. Expt. Agri. 1(2):1-9.

Margalef, R. 1958. Temporal succession and spatial heterogeneity in phytoplankton. In: A. A. BuzzatiTraverco (ed.). Perspective in Marine Biology. University of California Press, Berkclay. 470 pp.

Miah, M. D. and M. S. H. Chowdhury. 2004. Traditional forest utilization practice by the Mro tribe in the Bandarban region, Bangladesh. Schweiz Z Forstwes. 155: 65-70.

Mohiuddin, M. and A. K. Paul. 2018. Buddha Bihar (Kiyang) Based Traditional Model for Tree Diversity Conservation in Rangamati Hills, Bangladesh. J. Biodivers. Conserv. Bioresour. Manag. 4(1): 27-34.

Motaleb, M. A. and M. K. Hossain. 2011. Assessment of tree species diversity of Tankawati natural forests, Chittagong (South) Forest Division, Bangladesh. Eco-Friendly Agri. J. 4(2): 542-545.

Nath, T. K., M. K. Hossain and M. K. Alam. 2000. Assessment of tree species diversity of Sitapahar forest reserve, Chittagong Hill Tracts (South) Forest Division, Bangladesh. Indian Forester. 126: $16-21$.

Nath, T. K., M. K. Hossain and M. K. Alam. 1997. Studies on the structural composition of a natural forest of Chittagong Hill Tracts (South) Forest Division based on diameter class distribution. Chittagong Univ. Stud. part II, Science. 21(1): 15-22.

Ndah, N. R., E. E. Andrew and E. Bechem. 2013. Species composition, diversity and distribution in disturbed Takamanda Rainforest, South West, and Cameroon. African J. Plant Sci. 7: 577-585.

Panda, P. C., A. K. Mahapatra, P. K. Acharya and A. K. Debata. 2013. Plant diversity in tropical deciduous forests of Eastern Ghats, India: A landscape level assessment. Int. J. Biod. Conserv. 5: 625-639.

Pielou, E. C. 1966. Species diversity and pattern diversity in the study of ecological succession. J. Theoretical Biol. 10: 370-383.

Rasul, G. 2007. Political ecology of degradation of forest common in the Chittagong Hill Tracts of Bangladesh. Environ. Conserv. 34: 153-163.

Rasul, G. and G. B. Thapa. 2005. State policies, praxies and land use in the Chittagong Hill Tracts of Bangladesh. IIED Working Paper. International Institute for Environment and Development, London, UK. 18 pp.

Rasul, G. and M. Karki. 2006. Political ecology of degradation of forest common in the Chittagong Hill Tracts of Bangladesh. The Eleventh Biennial Conference of the International Association for the Study of Common Property, Bali, 19-23 June 2006.

Roy, R. C. K. 2000. Land rights of the indigenous peoples of the Chittagong Hill Tracts, Bangladesh. Copenhagen: International Work Group for Indigenous Affairs (IWGIA). 231 pp.

Roy, R. D. 2002. Land and forest rights in the Chittagong Hill Tracts, Bangladesh. ICIMOD Talking Points 4/02. International Centre for Integrated Mountain Development, Kathmandu, Nepal. 
Shannon, C. E. and W. Wiener. 1963. The mathematical theory of communication. Univ. Illinois Press, Urbana. $125 \mathrm{pp}$.

Shukla, R. S. and P. S. Chandal. 2000. Plant Ecology and Soil Science. 9th ed. S. Chand and Company Limited, Ramnagor, New Delhi, India., pp. 121-276.

Simpson, E. H. 1949. Measurement of Diversity. Nature. 163: 688.

Sobuj, N. A. and M. Rahman. 2010. Assessment of plant diversity in Khadimnagar National Park of Bangladesh. Int. J. Env. Sci. 2(1): 79-91.

Tripathi, K. P., S. Tripathi, T. Selven, K. Kumar, K. K. Singh, S. Mehrotra and P. Pushpangadan. 2004. Community structure and species diversity of Saddle Peak forests in Andaman Island. Tropical Ecol. 45: 241-150.

Uddin, S. M. M. and K. Misbahuzzaman. 2007. Tree species diversity in Dulahazara Safari Park of Bangladesh. Malays. Appl. Biol. 36(2): 33-40.

Velho, N. and M. Krishnadas. 2011. Post-logging recovery of animal-dispersed trees in a tropical forest site in north-east India. Tropical Conserv. Sci. 4: 405-419.

White, A. and A. Martin. 2002. Who owns the world's forests? Forest tenure and public forests in transition. Forest Trends, Washington DC. 30 pp. 
